\title{
Comparative leaf anatomy of Baccharis (Asteraceae) from high-altitude grasslands in Brazil: taxonomic and ecological implications
}

\author{
Thales Ornellas, Gustavo Heiden, Bruna Nunes de Luna, and Claudia Franca Barros
}

\begin{abstract}
Baccharis L. is an important genus in the high-altitude environments of South America. In the State of Rio de Janeiro, southeastern Brazil, the greatest richness is found at montane and high-montane ecological refuges, known as high-altitude grasslands. The high altitude provides several environmental factors that turn the highaltitude grasslands into singular tropical habitats. In this article we describe the leaf anatomy of six shrubby species of Baccharis, pointing out ecological aspects of the structures, and testing the use of statistical analyses to compare the species. Using light and scanning electron microscopy, we compared the anatomical features of the leaves and performed a cluster and principal component analyses. The results show novel features in the leaf anatomy for the genus, such as an undulated cuticle, three secretory ducts in the midrib, secretory ducts associated with the xylem, and biseriate glandular trichomes with an irregular organization of the cells. Our statistical analyses indicate that the anatomical features of the leaves, especially trichomes, are useful for distinguishing the different species, whereas others, such as isobilateral mesophyll, amphistomatic leaves, and an epidermis with thick cell walls correlate with their high-elevation habitat.
\end{abstract}

Key words: campos de altitude, secretory ducts, trichomes, morpho-anatomy.

Résumé : Baccharis L. est un genre important des environnements de haute altitude en Amérique du Sud. Dans l'état de Rio de Janeiro, dans le sud-est du Brésil, la richesse la plus élevée se trouve dans les refuges écologiques montagnards et de hautes montagnes, connus sous l'appellation de prairies de haute altitude. La haute altitude fournit plusieurs facteurs environnementaux qui transforment les prairies de haute altitude en habitats tropicaux singuliers. Les auteurs proposent ici de décrire l'anatomie foliaire de six espèces arbustives de Baccharis en signalant les aspects écologiques des structures, et de tester l'utilisation d'analyses statistiques pour comparer les espèces. À l'aide de la microscopie optique et de la microscopie électronique à balayage, ils ont comparé les caractéristiques anatomiques des feuilles et réalisé une analyse de groupement et une analyse en composantes principales. Les résultats présentent des nouveautés en ce qui concerne l'anatomie de la feuille chez ce genre, comme une cuticule ondulée, trois canaux sécrétoires dans la côte, des canaux sécrétoires associés au xylème et des trichomes glandulaires bisériés, dont les cellules ont une organisation irrégulière. L'analyse statistique indique que des caractères anatomiques des feuilles, particulièrement les trichomes, sont utiles pour distinguer les espèces alors que d'autres comme le mésophylle isobilatéral, les feuilles amphistomatiques et l'épiderme à parois cellulaires épaisses sont corrélés avec leur habitat en haute altitude. [Traduit par la Rédaction]

Mots-clés : campos de altitude, canaux sécrétoires, trichomes, morpho-anatomie.

\section{Introduction}

Baccharis L. (Asteraceae: Astereae) is a Neotropical plant genus comprising 354 species (Müller 2013) that occupy a wide range of environments, from sea level to high altitudes, and has its main diversity centers in the mountain regions of the northwest and southeast of South America. The dioecy and the tufted indument of the leaves and stems are synapomorphies of the genus (Müller 2006). In Brazil, there are 179 species with a widespread distribution in the different phytogeographical domains, and about 115 endemic species (Heiden 2019). In Rio de Janeiro State, the highest richness of Baccharis is found in montane and highmontane ecological refuges, such as the high-altitude grasslands and inselbergs, comprising 55 species, and seven endemics, of which six are restricted to the high altitude regions of the State (Heiden 2009).

Received 20 February 2019. Accepted 16 September 2019.

T. Ornellas, B.N. de Luna, and C.F. Barros. Instituto de Pesquisa Jardim Botânico do Rio de Janeiro, DIPEQ, R. Pacheco Leão 915, Rio de Janeiro, RJ 22460-030, Brazil.

G. Heiden. Embrapa Clima Temperado, BR 392 km 78, Pelotas, RS 96010-971, Brazil.

Corresponding author: Thales Ornellas (email: bio.puera@gmail.com).

Copyright remains with the author(s) or their institution(s). Permission for reuse (free in most cases) can be obtained from RightsLink. 
As reported by Safford (1999), the high-altitude grasslands are plant formations belonging to the Atlantic Rain Forest biome, restricted to the summits of the mountains in Brazilian south and southeast, above $1600 \mathrm{~m}$ a.s.1. The high altitude provides several environmental factors, such as the low atmospheric pressure that influences the increase in light irradiance and decrease in temperature, which turn the high-altitude grasslands into singular tropical habitats. Safford (1999) characterizes this ecosystem as a grassy archipelago surrounded by the Ombrophilous Forest, forming a mosaic of shrubby and graminoid formations with a low frequency of arboreal species, with their distribution controlled by the topography, drainage, and soil type. The highaltitude grasslands show a high degree of floristic richness and endemism, therefore considered reliquaries of biodiversity with phytogeographic connections with the "Cerrado" and Andean ecosystems. Asteraceae is the most speciose botanical family in high-altitude grasslands, with Baccharis being its most significant genus in these habitats (Safford 1999).

Baccharis species are commonly used in traditional medicine, known by the vernacular names "carqueja" (species with winged stem and reduced leaves) and "vassoura" (leafy species) (e.g., Budel and Duarte 2007, 2008a, 2008b, 2009, 2010; Molares et al. 2009; Rodriguez et al. 2010; Jasinski et al. 2014; Bobek et al. 2015, 2016; Budel et al. 2018). The pharmacological and phytochemical studies have contributed to improving the taxonomy of the genus with the identification of morpho-anatomical characters that can be used to determine species often commercialized as herbal medicines.

While floristic inventories are available (Nesom 1990; Giuliano 2001; Müller 2006; Heiden 2009; Giuliano and Freire 2011; Heiden et al. 2012), there was no infrageneric classification of the Brazilian species, with the exception of Heiden (2009), which is restricted to the 55 species of Rio de Janeiro State and recognized four subgenera and 15 sections. However, Heiden and Pirani (2016a, 2016b) recently presented novel features for the infrageneric classification, based on a broad phylogenetic study encompassing seven subgenera and 45 sections, which still needs to be tested from a morpho-anatomical point of view to identify new potential synapomorphies of the main clades. A comparative approach of the leaf anatomy of some Baccharis species has been explored recently (Bobek et al. 2016; Budel et al. 2018), identifying some characters that express the diversity of the leaf anatomy of the genus, and can be useful to differentiate the species, for example, the trichome types, occurrence, and types of the stomata, the mesophyll organization, among other characters.
In addition to its contribution to taxonomy and systematics, the knowledge of plant anatomy can be useful for identifying local adaptations, when the environmental context is considered (e.g., Starr 1912; Hayden 1919; Metcalfe and Chalk 1979; Morretes 1980; Mott and Michaelson 1991; Somavilla and Graciano-Ribeiro 2011; Aguiar-Dias et al. 2012; Jakovljević et al. 2014; Sanso et al. 2014; Perrone et al. 2015; Gavilanes et al. 2016).

Thus, the major objectives of this study are to describe the leaf anatomy of six shrubby species of Baccharis occurring in the high-altitude grasslands of Rio de Janeiro State, to test the usefulness of leaf anatomical characters for the segregation of Baccharis species, and to identify those that correlate with their high-altitude habitat.

\section{Materials and methods}

Samples of six shrubby species occurring in the highaltitude grasslands of Rio de Janeiro were collected between May and August 2018. The infrageneric classifications are based on Heiden (2009) and Heiden and Pirani (2016b). Samples of Baccharis itatiaiae Wawra (subgenus Baccharis section Cylindricae), B. phylicifolia DC. (subgen. Tarchonanthoides sect. Canescentes), and B. stylosa Gardner (subgen. Molina sect. Molinae) were collected at the plateau of the Parque Nacional de Itatiaia located in Serra da Mantiqueira $\left(22^{\circ} 14^{\prime} 33.19^{\prime \prime} \mathrm{N}\right.$; $22^{\circ} 27^{\prime} 54.14^{\prime \prime} \mathrm{S}$; $44^{\circ} 34^{\prime} 3.52^{\prime \prime} \mathrm{E}$; $44^{\circ} 46^{\prime} 10.77^{\prime \prime} \mathrm{W}$ ). This area is classified as having a subtropical highland climate (Cwb), in the Köppen climate classification, with annual precipitation of about $2400 \mathrm{~mm}$, concentrated in the summer, and an annual average temperature around $11.4^{\circ} \mathrm{C}$ (FBDS 2000). Baccharis calvescens DC. (subgen. Baccharis sect. Racemosae), B. parvidentata Malag. (subgen. Baccharis sect. Cylindricae), and B. platypoda DC. (subgen. Baccharis sect. Agglomeratae) were collected at the Parque Nacional da Serra dos Órgãos in the Serra do Mar chains of mountains $\left(22^{\circ} 52^{\prime} \mathrm{N}\right.$; $22^{\circ} 54^{\prime} \mathrm{S} ; 42^{\circ} 09^{\prime} \mathrm{E} ; 45^{\circ} 06^{\prime} \mathrm{W}$ ). This area is classified as having a temperate oceanic climate $(\mathrm{Cfb})$ with annual precipitation varying from 1500 to $3600 \mathrm{~mm}$, well distributed along the year, and an annual average temperature around $18.4{ }^{\circ} \mathrm{C}$ (ICMBio 2008). Voucher specimens (Supplementary data, Table $\mathrm{S}^{1}$ ) were deposited in the Herbarium of the Botanical Garden of Rio de Janeiro (RB).

Fully developed leaves were fixed in a solution of formalin-acetic acid-70\% ethanol (Johansen 1940) and stored, after $48 \mathrm{~h}$, in 70\% ethanol (Berlyn and Miksche 1976).

Samples of the midrib and leaf blade were dehydrated and embedded in glycol methacrylate (Leica Historesin ${ }^{\circledR}$ ), following the instructions of the manufacturer. Transverse sections were obtained using a rotary microtome (Leica RM2245), and the sections were stained with Toluidine Blue O (O’Brien et al. 1964).

1Supplementary data are available with the article through the journal Web site at http://nrcresearchpress.com/doi/suppl/10.1139/cjb2019-0035. 
To analyse the frontal view of epidermal features, the leaf epidermis was dissociated in a solution of hydrogen peroxide and acetic acid (1:1 v/v), washed in distilled water, and stained with $1 \%$ safranin (Franklin 1945). The classification of stomata followed the terminology of Metcalfe and Chalk (1950), and the trichomes were described according to the terminology of Freire et al. (2007): conical, aseptate flagellate, filiform flagellate, 1-armed, 2-4-armed, bulbiferous flagellate, and glandular biseriate; and according to Budel et al. (2018): type I and type II flagelliform.

Histochemical tests were performed on freehand sections of fixed leaf samples. Lipophilic compounds were detected using Sudan III (Sass 1951); lignified tissues using hydrochloric phloroglucinol (Foster 1949); and phenolic compounds using ferric chloride (Johansen 1940).

The images were obtained using a digital camera (Olympus DP73) coupled to an optical microscope (Olympus BX50).

Additional leaf samples were fixed in a solution of $2.5 \%$ glutaraldehyde and $4.0 \%$ formaldehyde buffered with $0.05 \mathrm{~mol} \cdot \mathrm{L}^{-1}$ sodium cacodylate $(\mathrm{pH} 7.2)$. The samples were rinsed three times in the same buffer, and then dehydrated in an increasing series of ethanol and acetone, then completely dehydrated using liquid $\mathrm{CO}_{2}$ in a critical point dryer (Leica EM CPD030), mounted on aluminium stubs, and sputter-coated with gold (Emitech $\mathrm{K} 550 \mathrm{X})$ for epidermal analysis under a scanning electron microscope (Zeiss EVO 40).

Cluster analysis and principal component analysis (PCA) were performed using the software Statistica 7.0 (StatSoft Inc 2004) using leaf anatomical characters to identify, through the factor analysis, the most significant features in the distinction of species. Leaf anatomical data of an additional eight species of Baccharis from Bobek et al. (2016) and Budel et al. (2018) were included in the analyses, totalling 14 species.

\section{Results}

\section{Epidermis and cuticle}

The epidermis of all the analysed species had thick, straight to slightly undulated, anticlinal walls with conspicuous pits. Baccharis stylosa has a smooth cuticle on both leaf sides (Figs. 1I, 1L), showing striations only radiating from the trichome bases. In B. platypoda, the cuticle was undulated (Figs. $1 \mathrm{H}, 1 \mathrm{~K})$. In B. calvescens, B. itatiaiae, B. parvidentata, and B. phylicifolia, the cuticle was smooth on the adaxial side (Figs. $1 \mathrm{~A}-1 \mathrm{C}, 1 \mathrm{G}$ ), with striations around the trichomes or stomata in B. calvescens (Fig. 1A) and $B$. itatiaiae, and striated on the abaxial side of several species (Figs. 1D-1F and 1J).

In the transverse sections (Figs. 2A-2R), all of the species have a single-layered epidermis covered with a thin cuticle, showing thick outer periclinal walls (Fig. 3P). Baccharis calvescens, $B$. parvidentata, and B. phylicifolia have epidermal cells with greater volume on the adaxial side in relation to the abaxial side (Figs. 2C, 2I, and $2 \mathrm{~L}$ ), whereas the volume of the epidermal cells was relatively uniform in the other species (Figs. 2F, 2O, and 2R).

\section{Stomata}

Baccharis calvescens, B. parvidentata, and B. phylicifolia are hypostomatic (Figs. 2B, $2 \mathrm{H}$, and $2 \mathrm{~K}$ ) and $\mathrm{B}$. itatiaiae, B. platypoda, and B. stylosa are amphistomatic (Figs. 2E, $2 \mathrm{~N}$, and $2 \mathrm{P}$ ), with the latter showing stomata on the adaxial side only along the veins. The stomata are at the same level as the other epidermal cells in B. platypoda (Fig. $2 \mathrm{~N}$ ) and B. stylosa (Fig. 2Q), at the same level or slightly elevated in B. calvescens (Fig. 2B), B. itatiaiae (Fig. 2E), and B. parvidentata (Fig. $2 \mathrm{H}$ ), and protruded in B. phylicifolia (Fig. 2K). Baccharis itatiaiae and B. parvidentata present preferentially tetracytic and staurocytic stomata, also occurring, with lower frequency, anomocytic stomata. Baccharis platypoda presents tetracytic and staurocytic stomata, rarely ciclocytic and anomocytic. In B. stylosa, anisocytic and anomocytic stomata occur. In B. phylicifolia, the high stomata density leads to an anomocytic type with indistinct subsidiary cells. This characteristic is also found in B. calvescens, which also rarely presents actinocytic stomata.

\section{Indumentum}

We found different types of trichomes in the studied species, and these were often located in depressions in the epidermis and usually occurred in tufts, except in B. parvidentata and B. phylicifolia, which have isolated trichomes. In B. itatiaiae, the tufts are composed of biseriate glandular trichomes and type I flagelliform glandular trichomes on both sides of the leaf (Figs. 3B and 3E). Baccharis stylosa has trichomes clustered in tufts on both sides of the leaf blade, and these are biseriate on the adaxial side (Fig. 3I), and type II flagelliform on the abaxial one (Fig. 3L). Similarly, tufts of biseriate and capitate uniseriate trichomes are found on the adaxial side of B. calvescens (Figs. 1A and 3A), whereas on the abaxial side there are branched uniseriate glandular trichomes (Figs. 1D and 3D). In B. platypoda, tufts of trichomes are also present on both sides, with biseriate and capitate uniseriate glandular trichomes on the adaxial side (Fig. $3 \mathrm{H}$ ), and biseriate glandular trichomes on the abaxial side (Fig. 3K). Baccharis parvidentata presents bulbiferous flagellate glandular trichomes, subtype B, singled or rarely tufted, in deep depressions along the veins on the adaxial side, and scattered across the leaf blade on the abaxial side (Figs. 1F, 3C, and 3F). In B. phylicifolia, the adaxial indument is composed of conical trichomes with a multicellular pedestal, followed by a globular cell with dense cytoplasm, ending with a series of elongated filiform cells with thick lateral walls (Figs. 1G and 3G). Three types of trichomes densely cover the abaxial side of the epidermis: (i) biseriate glandular trichomes with an irregular organization, showing two series of cells without alignment (Figs. 1J and 3J detail); (ii) uniseriate conical 
Fig. 1. Scanning electron micrographs of leaf epidermis from Baccharis species. (A, B, C, G, H, and I) Adaxial side. (D, E, F, J, K, and L) Abaxial side. (A and D) Baccharis calvescens. (B and E) Baccharis itatiaiae. (C and F) Baccharis parvidentata. (G and J) Baccharis phylicifolia. (H and K) Baccharis platypoda. (I and L) Baccharis stylosa. bi, biseriate trichome; br, branched trichome; bu, bulbiferous flagellate trichome; co, conical trichome; fl, flagelliform trichome; ib, irregular biseriate trichome; tt, trichomes in a tuft. Scale bars $=20 \mu \mathrm{m}$.
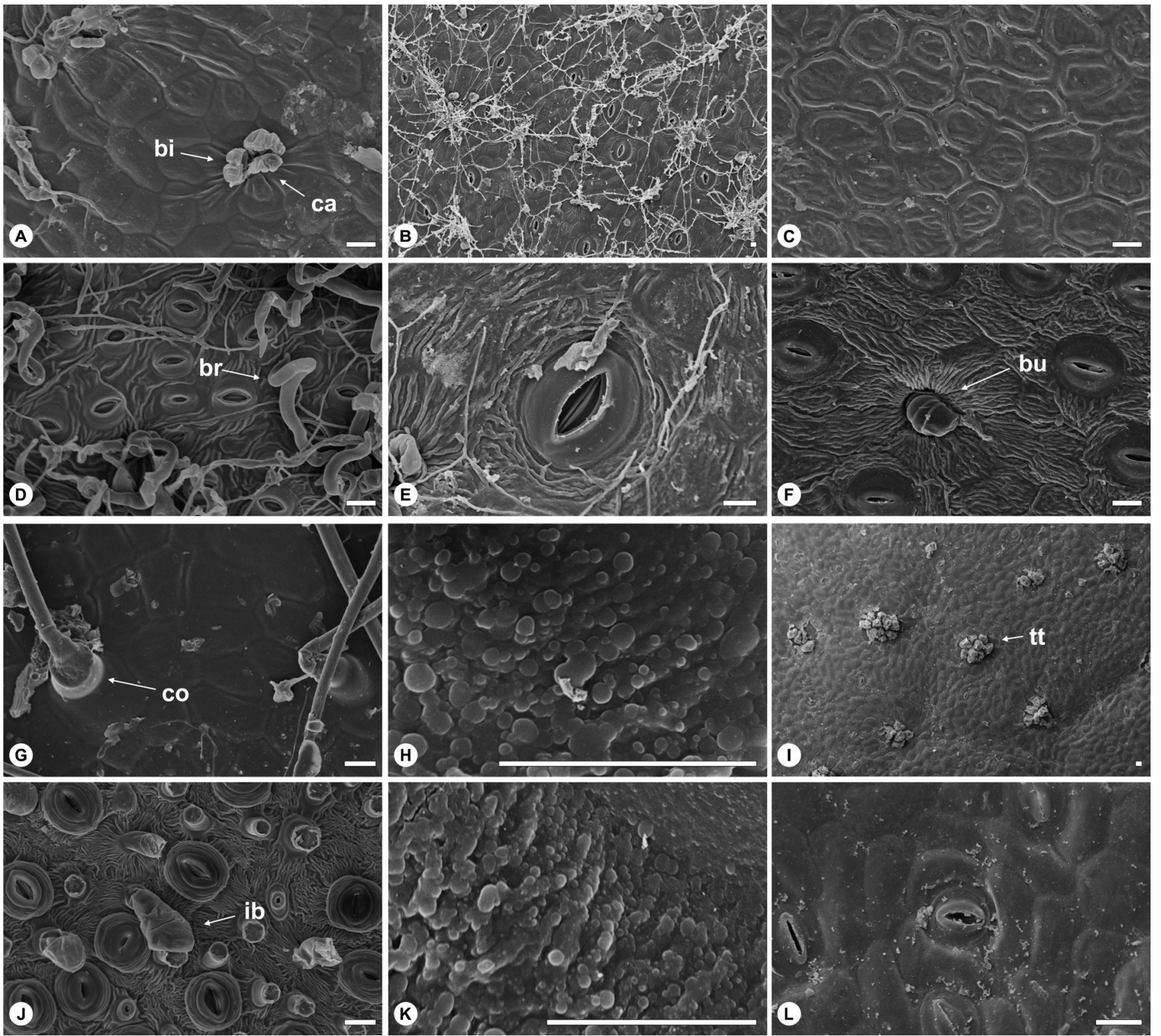

trichomes with a multicellular pedestal, a large cylindrical cell, ending with a series of elongated filiform cells with thick lateral walls; and (iii) uniseriate aseptate trichomes with a multicellular pedestal, a small cylindrical cell, and a terminal aseptate filiform cell (Fig. 3J).

\section{Midrib and vascular system}

The shape of midrib and the arrangement of vascular bundles and secretory ducts vary among the species we studied. Baccharis itatiaiae has a flat-convex shape (Fig. 2D), and in B. platypoda it is biconvex (Fig. 2M). The other species have a concave-convex shape (Figs. 2A, 2G,
2J, and 2P). Some layers of angular collenchyma are found in all the species, mainly on the abaxial side. All of the six species present collateral vascular bundles surrounded by sclerenchyma fibres, mainly below the phloem. Baccharis calvescens, B. itatiaiae, B. parvidentata, and B. phylicifolia have a single vascular bundle associated with an abaxial schizogenous secretory duct (often inconspicuous in B. phylicifolia) composed of a singlelayered epithelium with a variable number of cells (Figs. 2A, 2D, 2G, and 2J). In B. stylosa, the single vascular bundle has three associated secretory ducts (Fig. 2P), and 
Fig. 2. Midrib and leaf blade in transverse sections of Baccharis species. (A-C) Baccharis calvescens. (D-F) Baccharis itatiaiae. (G-I) Baccharis parvidentata. (J-L) Baccharis phylicifolia. (M-O) Baccharis platypoda. (P-R) Baccharis stylosa. bu, bulbiferous flagellate trichome; co, conical trichome; ib, irregular biseriate trichome; pa, palisade parenchyma; sd, secretory duct; sp, spongy parenchyma; st, stomata; tt, trichomes in tuft; vb, vascular bundle. Scale bars $=100 \mu \mathrm{m}$. [Colour online.]
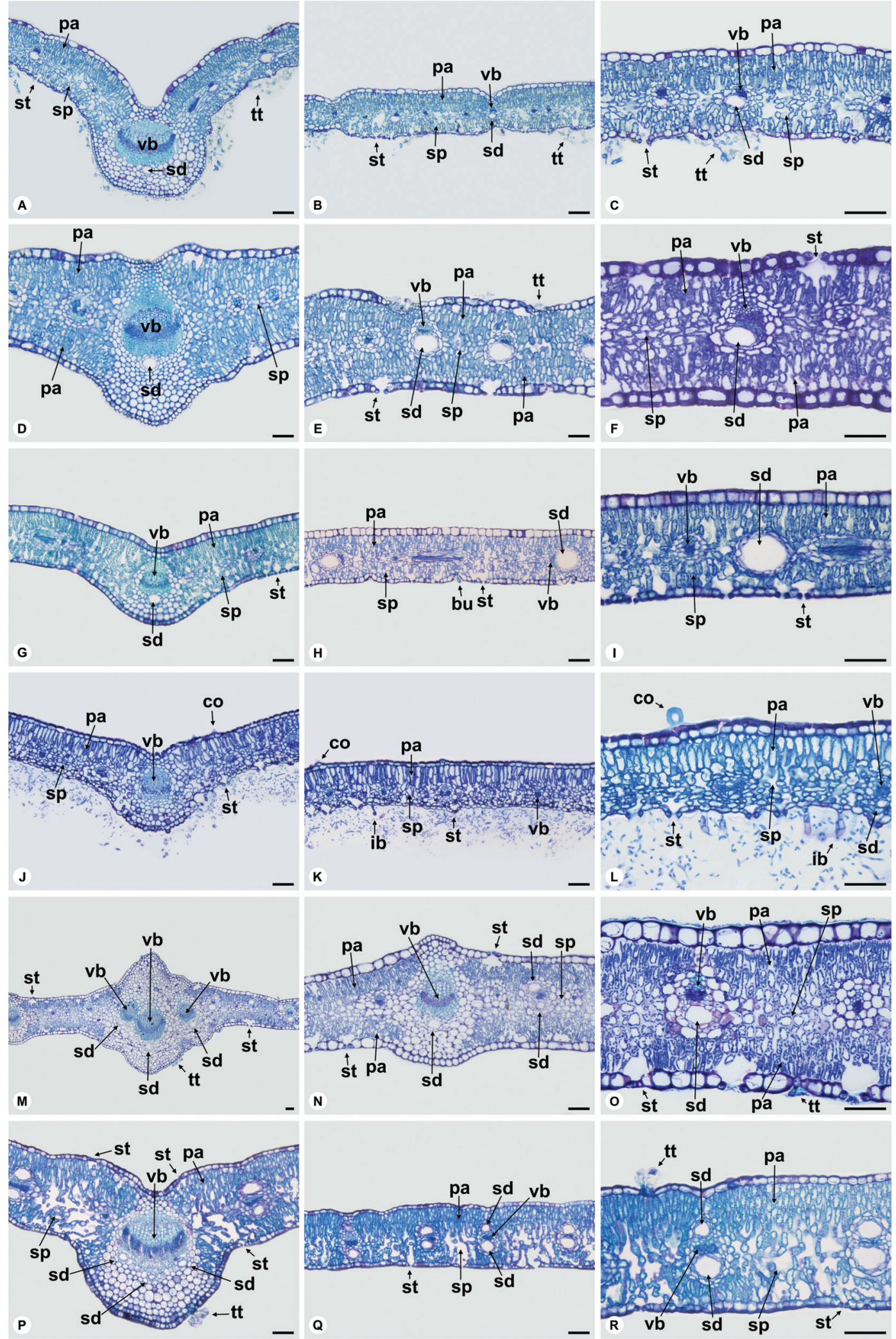
Fig. 3. Frontal view of leaf epidermis (A-L) and histochemical tests (M-R) of Baccharis species. (A-C and G-I) Adaxial side. (D-F and J-L) Abaxial side. (M-R) Transverse section. (M, O, P, and R) Section stained with Sudan III. (N) Section stained with ferric chloride. (Q) Section stained with hydrochloric phloroglucinol. (A, D, and M) Baccharis calvescens. (B, E, and N) Baccharis itatiaiae. (C, F, and $\mathrm{O}$ ) Baccharis parvidentata. (G, J, and $\mathrm{P}$ ) Baccharis phylicifolia. (H, K, and Q) Baccharis platypoda. (I, L, and R) Baccharis stylosa. as, aseptate trichome; bi, biseriate trichome; br, branched trichome; bu, bulbiferous flagellate trichome; ca, capitate trichome; co, conical trichome; cu, cuticle; et, epidermal thickening; fl, flagelliform trichome; ib, irregular biseriate trichome; lp, lignified parenchyma; ob, oil bodies; pa, palisade parenchyma; sd, secretory duct; sp, spongy parenchyma; tt, trichomes in a tuft; vb, vascular bundle. Scale bars $=100 \mu \mathrm{m}$. [Colour online.]
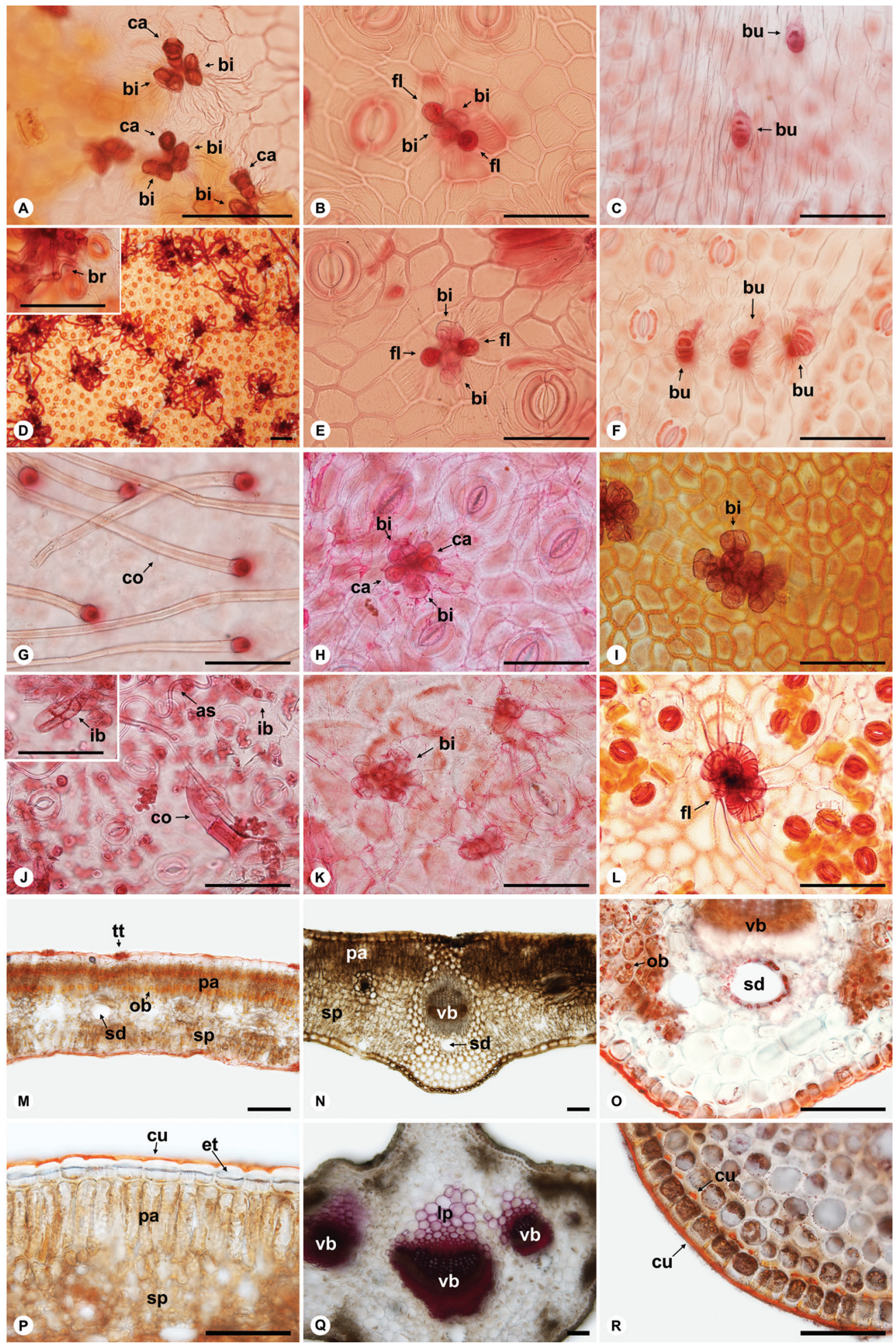

N

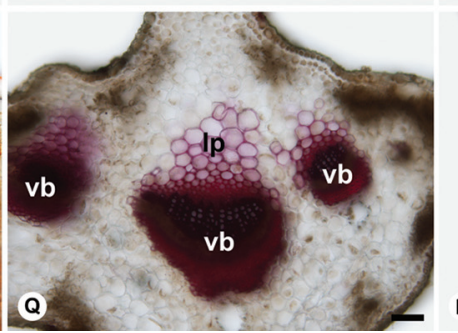


in B. platypoda is observed three vascular bundles, owing to the pinnate venation of the leaves, each one associated to one secretory duct (Fig. 2M).

\section{Leaf blade and mesophyll}

The mesophyll of B. itatiaiae and B. platypoda is isobilateral with two to three layers of palisade parenchyma on each side and a compact arrangement of spongy parenchyma (Figs. 2F and 2O). Baccharis calvescens, B. parvidentata, B. phylicifolia, and B. stylosa have a dorsiventral organization, presenting one to three layers of palisade parenchyma (Figs. 2C, 2I, 2L, and 2R). In B. platypoda there are ridges on the larger lateral vascular bundles (Fig. 2N), whereas in B. calvescens there are depressions (Fig. 2B). In all of the analysed species, the collateral vascular bundles are arranged along the mesophyll, surrounded by a parenchymatous sheath and usually associated with an abaxial secretory duct, except in B. stylosa, which has a second secretory duct associated with the xylem on the adaxial side (Figs. 2Q and 2R). This adaxial duct also occurs in B. platypoda, but less frequently (Fig. 2N). In B. parvidentata, the secretory ducts are large and often are arranged laterally or isolated (Figs. 2H and 2I).

\section{Histochemical tests}

The hydrochloric phloroglucinol test revealed slightly lignified parenchymatic cells above the sclerenchyma fibres in B. platypoda (Fig. 3Q). The test for lipids showed the presence of oil bodies in B. calvescens, B. parvidentata, and $B$. platypoda, mostly in the palisade parenchyma (Figs. 3M and 30) and the epithelium of the secretory ducts (Fig. 30). The presence of an internal cuticle in the epidermis of the midrib in B. stylosa. (Fig. 3R) was also observed. The presence of phenolic compounds was detected in the epidermis of the midrib of $B$. itatiaiae (Fig. $3 \mathrm{~N}$ ) and B. stylosa, and in the palisade parenchyma of all the species (Fig. 3N).

\section{Statistical analyses}

The cluster analysis and PCA were performed from a presence/absence matrix of 38 characteristics of the leaf anatomy (see the Supplementary data, Table S2 ${ }^{1}$ ). The PCA results show that the three first factors explain $59.16 \%$ of the total variance. The factor analysis (Table 1 ) indicates that the features that most influenced the distinction of the species were cuticle ornamentation, stomata type, stomata position, stomata occurrence, mesophyll organization, number of secretory ducts in the midrib and leaf blade, number of vascular bundles in the midrib, and trichome type. The first factor $(26.57 \%)$ was weighted for stomata at the same level as the epidermal cell, protruded stomata, tetracytic stomata, staurocyric stomata, hypostomatic leaves, isobilateral mesophyll, and dorsiventral mesophyll. The second factor (19.70\%) was weighted for anisocytic stomata, the single secretory duct in the leaf blade, the double secretory duct in the leaf blade, the single secretory duct in the midrib, and three secretory ducts in the midrib. The third factor (12.89\%) was weighted for undulated cuticle, capitate trichomes, single vascular bundle in the midrib, and multiple vascular bundles in the midrib. The 3D graphic of the PCA (Fig. 4) shows the distinction between two groups and the isolation of B. platypoda and B. stylosa.

The cluster analysis (Fig. 5) segregates the studied species into two major groups, distinguished by the mesophyll organization. In each respective group, B. stylosa and B. platypoda segregate first due to the presence of a second secretory duct in the leaf blade and the conformation of the vascular bundles and secretory ducts in the midrib, followed by the segregation of a group characterized by hypostomatic leaves in the cluster of dorsiventral mesophyll and a group of amphistomatic and amphihypostomatic leaves in the cluster of isobilateral mesophyll. The proposed anatomical characters did not distinguish B. illinita and B. reticularioides.

\section{Discussion}

\section{Taxonomic evaluation}

In general, the cuticle in Baccharis species is described as smooth or striated, on both or one of the leaf sides, or even presenting striations only around stomata and trichomes (Müller 2006; Jasinski et al. 2014; Bobek et al. 2015, 2016; Budel et al. 2018). In the studied species, only B. platypoda presented a different pattern, showing an undulated cuticle on both sides of the leaf, which is reported herein for the first time for Baccharis.

Regarding the anticlinal walls, Budel et al. (2018) suggest that sinuous walls can be a common character in species of the subgenus Molina. However, B. stylosa belongs to this subgenus (Heiden 2009) and has straight anticlinal walls on both sides of the epidermis.

Amphistomatic leaves are frequent in Baccharis, being reported in B. brevifolia (Bobek et al. 2016), B. caprariifolia (Bobek et al. 2015), B. cognata (Budel et al. 2013), B. dracunculifolia (Budel et al. 2004), B. glaziovii (Jasinski et al. 2014), B. obovata (Molares et al. 2009), B. pauciflosculosa (Bobek et al. 2016; Budel et al. 2018), B. sphenophylla (Budel et al. 2018), B. spicata (Oliveira et al. 2011), B. trilobata (Bobek et al. 2016), and B. junciformis (as B. usterii) (Budel and Duarte 2010). Hypostomatic leaves also occur in the genus, as reported in B. anomala (Budel and Duarte 2008b), B. erioclada (Bobek et al. 2015), B. microdonta (Bobek et al. 2016), B. ochracea (Barreto et al. 2015), B. punctulata (Budel et al. 2018), B. singularis (Souza et al. 2011), and B. uncinella (Budel and Duarte 2008a). In the current study, B. itatiaiae, B. platypoda, and $B$. stylosa were found to have amphistomatic leaves, whereas B. calvescens, B. parvidentata, and B. phylicifolia have hypostomatic leaves.

Analysing 38 medicinal species of Baccharis, Freire et al. (2007) reported seven types of trichomes occurring isolated or in tufts composed of similar or distinct trichomes. Biseriate glandular trichomes and uniseriate flagelliform trichomes are among the most com- 
Table 1. Factor loadings and percentage of variance for the three principal components obtained from the 38 characters analysed.

\begin{tabular}{|c|c|c|c|}
\hline & Factor 1 & Factor 2 & Factor 3 \\
\hline Adaxial epidermal cells $>$ abaxial epidermal cells & 0.591347 & -0.483444 & 0.065340 \\
\hline Adaxial epidermal cells = abaxial epidermal cells & -0.591347 & 0.483444 & -0.065340 \\
\hline Striated cuticle & 0.542772 & -0.522609 & 0.165202 \\
\hline Smooth cuticle & 0.464356 & 0.216000 & -0.320855 \\
\hline Undulated cuticle & -0.365225 & 0.407033 & 0.810206 \\
\hline Cuticle with striations around stomata and trichomes & -0.271418 & 0.345645 & -0.601147 \\
\hline Stomata at the same level of the epidermal cells & -0.743205 & 0.069009 & -0.301896 \\
\hline Protruded stomata & 0.743205 & -0.069009 & 0.301896 \\
\hline Tetracytic stomata & -0.820462 & -0.338856 & 0.066411 \\
\hline Staurocytic stomata & -0.820462 & -0.338856 & 0.066411 \\
\hline Anisocytic stomata & 0.087128 & 0.774042 & -0.443198 \\
\hline Actinocytic stomata & -0.201368 & -0.576355 & -0.099945 \\
\hline Anomocytic stomata & 0.577823 & 0.532138 & 0.342219 \\
\hline Cyclocytic stomata & -0.482046 & 0.123530 & 0.192958 \\
\hline Amphistomatic leaves & -0.591347 & 0.483444 & -0.065340 \\
\hline Hypostomatic leaves & 0.913022 & -0.079147 & 0.211251 \\
\hline Amphi-hypostomatic leaves & -0.284621 & -0.501960 & -0.152961 \\
\hline Isobilateral mesophyll & -0.907635 & -0.341415 & 0.039042 \\
\hline Dorsiventral mesophyll & 0.907635 & 0.341415 & -0.039042 \\
\hline Tufted trichomes & -0.509642 & 0.268681 & -0.154666 \\
\hline Isolated trichomes & 0.509642 & -0.268681 & 0.154666 \\
\hline Biseriate trichomes & -0.169211 & 0.260716 & -0.043486 \\
\hline Type I flagelliform trichomes & -0.528905 & -0.570730 & -0.254002 \\
\hline Type II flagelliform trichomes & 0.228928 & 0.605091 & -0.371078 \\
\hline Capitate trichomes & 0.046010 & 0.284899 & 0.760316 \\
\hline Branched trichomes & 0.427740 & -0.019931 & 0.222859 \\
\hline Bulbiferous flagelliform trichomes, subtype b & 0.169211 & -0.260716 & 0.043486 \\
\hline Conical trichomes & 0.582077 & -0.073834 & 0.187336 \\
\hline Aseptate trichomes & 0.582077 & -0.073834 & 0.187336 \\
\hline Single secretory duct in the leaf blade & 0.204674 & -0.869247 & -0.270111 \\
\hline Double secretory duct in the leaf blade & -0.204674 & 0.869247 & 0.270111 \\
\hline Single secretory duct in the midrib & -0.087128 & -0.774042 & 0.443198 \\
\hline Three secretory ducts in the midrib & 0.087128 & 0.774042 & -0.443198 \\
\hline Single vascular bundle in the midrib & 0.365225 & -0.407033 & -0.810206 \\
\hline Multiple vascular bundles in the midrib & -0.365225 & 0.407033 & 0.810206 \\
\hline Biconvex midrib & -0.462733 & -0.270372 & 0.462946 \\
\hline Flat-convex midrib & -0.162389 & 0.053264 & -0.218718 \\
\hline Concave-convex midrib & 0.570656 & 0.198192 & -0.222949 \\
\hline Percentage of total variance (\%) & 26.57227 & 19.70277 & 12.89229 \\
\hline
\end{tabular}

Note: Bold font indicates the values for loadings greater than $|0.7|$.

mon types found in the genus. Flagelliform trichomes have been considered as nonglandular, but Budel et al. (2018) suggest that these trichomes exhibit secretory activity, owing the presence of lipophilic compounds in their cells, classifying them as flagelliform glandular trichomes. In the leaves of the studied species, the trichome type was the most diagnostic feature, showing different morphologies and configurations among species. It is worth mentioning that in B. calvescens the indumentum is composed of tufts of branched trichomes, which was also seen in B. coridifolia (Budel and Duarte 2007), B. dracunculifolia (Budel et al. 2004), B. erioclada (Bobek et al. 2015), and B. uncinella (Budel and Duarte 2008a), all of which belong to section Racemosae (Heiden 2009), except B. coridifolia, which belongs to section Coridifoliae (Giuliano 2011). In B. phylicifolia there are four distinct types of trichomes in its leaves. The conical trichomes present on the adaxial side are similar to those illustrated by Hellwig (1992) for the adaxial side of B. helichrysoides, which also belongs to section Canescentes (Heiden and Pirani 2016b), but in B. phylicifolia the filiform portion is composed of a series of cells instead of a single one. Hellwig (1992) also depicts trichomes on the abaxial side of B. grisebachii leaves, similar to the aseptate trichomes in B. phylicifolia. These trichomes and the abaxial conical trichomes have similar cylindrical cells, only differing in size. The biseriate trichomes with an irregular organization of the cells are reported for the first time herein.

The occurrence of single secretory ducts associated with the phloem in Baccharis species is well-documented in the literature for the genus, and it is present in the species analysed in this study, except in B. platypoda and 
Fig. 4. Scatterplot based on principal component analysis.

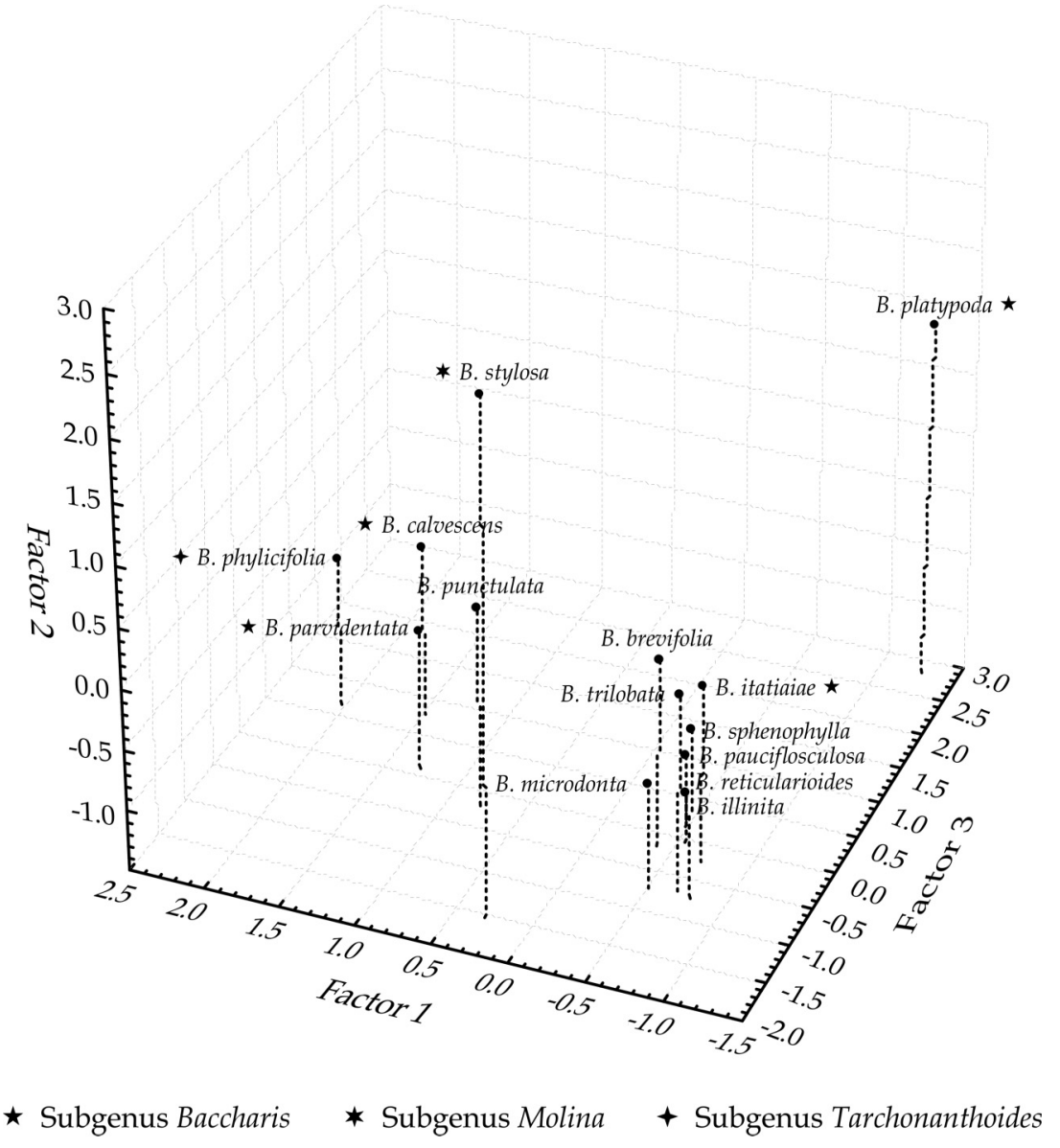

Fig. 5. Dendrogram based on cluster analysis.

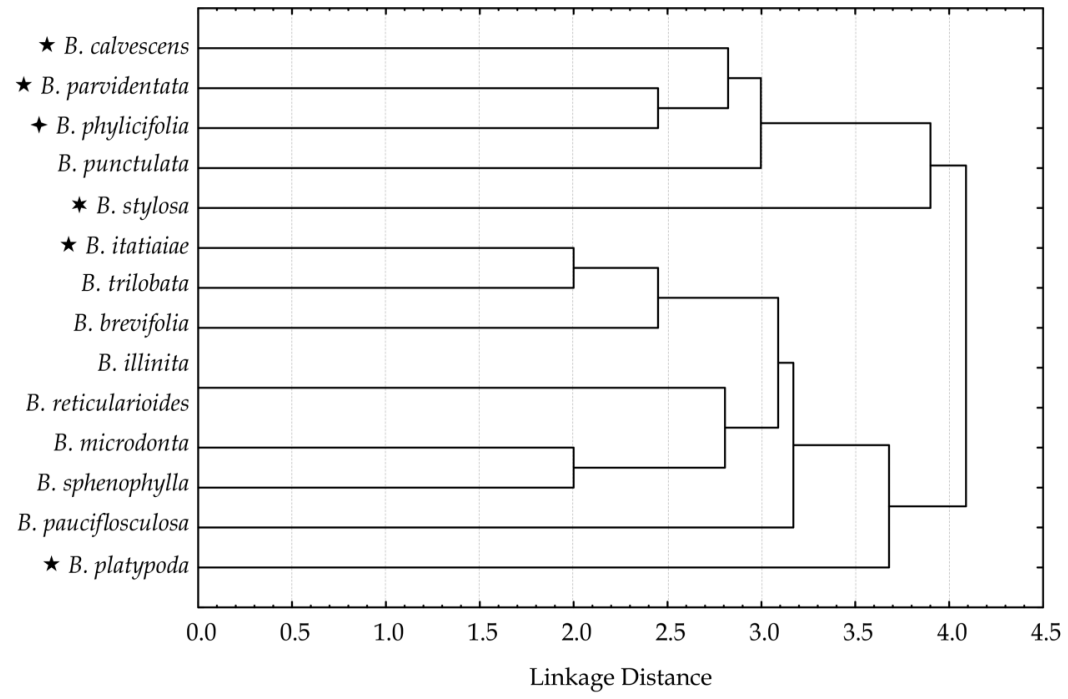

$\star$ Subgenus Baccharis

* Subgenus Molina

+ Subgenus Tarchonanthoides

B. stylosa, where there is a second duct associated with the xylem. This feature is commonly found in the Asteraceae family in species of the tribes Eupatoriae and $\mathrm{He}$ lianthae, and rarely in the tribe Astereae (Castro et al. 1997). Smiljanic (2005), studying the leaf anatomy of As- teraceae species, B. platypoda and B. stylosa among them, reported for the first time the presence of a second duct associated with the xylem in Baccharis, but only recording it for B. stylosa. This study provides the first reported occurrence of the second duct for B. platypoda. The pres- 
ence of three secretory ducts associated with the vascular bundle on the midrib of B. stylosa is especially noteworthy, as it is a novel finding for the genus.

The results of the cluster analysis and PCA concurs with the formation of two major groups distinguished by the mesophyll organization and stomata occurrence, as well as the segregation of B. platypoda and B. stylosa, both of which characterized by the presence of a second secretory duct in the leaf blade. Considering the six species studied here, their grouping does not reflect the current infrageneric classification (Heiden 2009; Heiden and Pirani 2016b), as demonstrated by the separation of the species belonging to the subgenus Baccharis.

\section{Ecological interpretation}

All of the studied species present a thickening in the periclinal walls of the ordinary epidermal cells; a feature that is also found in other plants from high altitudes (Körner et al. 1989; Gavilanes et al. 2016). Such thickening can be an adaptation to the environmental conditions present at high altitudes, serving as a filter to reflect or absorb the high UV-radiation (Robberecht et al. 1980), thus compensating for the thin cuticle layer observed in all of the studied species.

The sinuosity and thickness of the anticlinal walls can also reflect ecological influences (Wilkinson 1979). Straight and thick walls tend to decrease the excessive loss of water (Medri and Lleras 1980; Fahn and Cutler 1992); an advantageous feature in a mountaintop environment where the shallow soils make water retention difficult. These features are common in Baccharis (Oliveira et al. 2011; Souza et al. 2011; Barreto et al. 2015; Bobek et al. 2015, 2016; Budel et al. 2018) and were found in all of the studied species. Baccharis stylosa also shows an additional anatomical strategy to minimize the water evaporation, presenting an internal cuticle on the inner side of the epidermis (Pesacreta and Hasenstein 1999).

Amphistomatic leaves are common in Baccharis. Mott et al. (1982) suggested that the presence of stomata on both sides of the leaf has an adaptative significance, being a derived character and ecologically correlated with the increased leaf conductance of carbon dioxide in plants growing in sunny environments with seasonal or perennial variations of water availability on the soil. Such environmental characteristics, in addition to the greater diffusion of gases due to the low atmospheric pressure, are present in regions of high altitude, where there is great diversity of Baccharis species. The occurrence of stomata and the mesophyll organization seem to be correlated in the studied species, and in the genus in general: amphistomatic leaves tend to be isobilateral, whereas hypostomatic leaves present dorsiventral mesophyll. Even B. stylosa, which has dorsiventral mesophyll and amphistomatic leaves, shows a tendency to have hypostomatic leaves with few scattered stomata along the veins on the adaxial side.
The presence of oil bodies in the mesophyll of Baccharis was first reported by Budel et al. (2018), and it was observed here in the mesophyll of B. calvescens, B. parvidentata (including in the epithelium of secretory ducts), and B. platypoda. The absence of oil bodies in the other studied species is not conclusive, owing to the use of ethanolic fixative in specimens preparations, which can dissolve lipids. Oil bodies are widely found in leaves of Asteraceae and other families (Lersten et al. 2006), despite their uncertain physiological function, some studies suggest that they can be a site of energy storage, a chemical source for defence responses to pathogens and an adaptation to low temperatures (Pihakaski et al. 1987; Lersten et al. 2006; Shimada et al. 2014).

Regarding the groups established in the statistical analyses (supported by the mesophyll organization and the stomata occurrence), it is not possible to assign an ecological influence in the anatomical patterns, because species sharing the same habitat show different features, and species with the same features occur in different habitats. Considering that the mesophyll organization and distribution of stomata are also features associated with physiological traits, we suggest that two functional patterns are present in Baccharis from the same environment.

\section{Conclusions and future perspectives}

This study increases the knowledge about the anatomy of the genus Baccharis, presenting first reports on the leaf anatomical characters, such as undulated cuticle, irregular biseriate glandular trichomes, adaxial secretory ducts in the leaf blade, and three secretory ducts on the midrib. The leaf structure of the studied species shows two functional patterns formed by the mesophyll organization and the distribution of stomata, and some characters, such as thick anticlinal walls and oil bodies in the mesophyll, can be narrowly linked to the environmental conditions. Features of the leaf anatomy showed potential for segregating the species, but considering the morpho-anatomical diversity of Baccharis, further studies integrated with phylogenetic analysis are required to address the evolution of the anatomical features and their ecological significance.

\section{Acknowledgements}

We thank the anonymous reviewers and the associate editor, Julien B. Bachelier, for their valuable comments and suggestions. This study was financed in part by the Coordenação de Aperfeiçoamento de Pessoal de Nível Superior - Brasil (CAPES); Finance Code 001.

\section{References}

Aguiar-Dias, A.C.A., Yamamoto, K., and Castro, M.M. 2012. Anatomia foliar de cinco espécies de Polygala de restinga e cerrado. Rodriguésia, 63(2): 395-404. doi:10.1590/S217578602012000200012.

Barreto, I.F., Paula, J.P., Farago, P.V., Duarte, M.R., and Budel, J.M. 2015. Pharmacobotanical study of leaves and 
stems of Baccharis ochracea Spreng. for quality control. Lat. Am. J. Pharm. 34: 1497-1502.

Berlyn, G.P., and Miksche, J.P. 1976. Botanical microtechnique and cytochemistry. The Iowa State University Press, Ames, Iowa.

Bobek, V.B., Almeida, V.P., Pereira, C.B., Heiden, G., Duarte, M.R., Budel, J.M., and Nakashima, T. 2015. Comparative pharmacobotanical analysis of Baccharis caprariifolia DC. and B. erioclada DC. from Campos Gerais, Paraná, Southern of Brazil. Lat. Am. J. Pharm. 34: 1396-1402.

Bobek, V.B., Heiden, G., Oliveira, C.F., Almeida, V.P., Paula, J.P., Farago, P.V., Nakashima, T., and Budel, J.M. 2016. Comparative analytical micrographs of "vassouras" (Baccharis, Asteraceae). Rev. Bras. Farmacogn. 26: 665-672. doi:10.1016/j.bjp. 2016.05.001.

Budel, J.M., and Duarte, M.R. 2007. Caracteres morfoanatômicos de partes vegetativas aéreas de Baccharis coridifolia DC. (Asteraceae-Astereae). Lat. Am. J. Pharm. 26(5): 723-731.

Budel, J.M., and Duarte, M.R. 2008a. Estudo farmacobotânico de folha e caule de Baccharis uncinella DC., Asteraceae. Lat. Am. J. Pharm. 27(5): 740-746.

Budel, J.M., and Duarte, M.R. 2008b. Estudo farmacobotânico de partes vegetativas aéreas de Baccharis anomala DC., Asteraceae. Rev. Bras. Farmacogn. 18: 761-768. doi:10.1590/S0102695X2008000500022.

Budel, J.M., and Duarte, M.R. 2009. Análise morfoanatômica comparativa de duas espécies de carqueja: Baccharis microcephala DC. e B. trimera (Less.) DC., Asteraceae. Braz. J. Pharm. Sci. 45(1): 75-85. doi:10.1590/S1984-82502009000100009.

Budel, J.M., and Duarte, M.R. 2010. Macro and microscopic characters of the aerial vegetative organs of carqueja: Baccharis usterii Heering. Braz. Arch. Biol. Technol. 53(1): 123-131. doi: 10.1590/S1516-89132010000100016.

Budel, J.M., Duarte, M.R., and Santos, C.A.M. 2004. Morfoanatomia foliar e caulinar de Baccharis dracunculifolia DC., Asteraceae. Lat. Am. J. Pharm. 23(4): 477-483.

Budel, J.M., Farago, P.V., and Duarte, M.R. 2013. Pharmacobotanical study of Baccharis cognata DC. (Asteraceae: Astereae). Lat. Am. J. Pharm. 32(4): 550-554.

Budel, J.M., Raman, V., Monteiro, L.M., Almeida, V.P., Bobek, V.B., Heiden, G., et al. 2018. Foliar anatomy and microscopy of six Brazilian species of Baccharis (Asteraceae). Microsc. Res. Tech. 81(8): 832-842. doi:10.1002/jemt.23045. PMID:29702730.

Castro, M.M., Leitão-Filho, H.F., and Monteiro, W.R. 1997. Utilização de estruturas secretoras na identificação dos gêneros de Asteraceae de uma vegetação de cerrado. Rev. Bras. Bot. 20(2): 163-174. doi:10.1590/S0100-84041997000200007.

Fahn, A., and Cutler, D.F. 1992. Xerophytes. G. Borntraeger, Berlin, Germany.

FBDS. 2000. Cadernos FBDS 3: O Parque Nacional do Itatiaia. Fundação Brasileira para o Desenvolvimento Sustentável (FBDS), Rio de Janeiro, Brazil.

Foster, A.S. 1949. Practical plant anatomy. D. Van Nostrand Company Inc., New York, N.Y.

Franklin, G.L. 1945. Preparation of thin sections of synthetic resins and wood-resin composites, and a new macerating method for wood. Nature, 155: 51. doi:10.1038/155051a0.

Freire, S.E., Urtubey, E., and Giuliano, D.A. 2007. Epidermal characters of Baccharis (Asteraceae) species used in traditional medicine. Caldasia, 29(1): 23-38.

Gavilanes, M.L., Castro, E.M., Pires, M.F., Pereira, F.J., and Pereira, M.P. 2016. Micromorfometria foliar de Palicourea rigida Kunth. (Rubiaceae) em ambiente de cerrado e campo rupestre. Cerne, 22(2): 163-170. doi:10.1590/01047760201622022070.

Giuliano, D. 2001. Classificación infragenérica de las espécies Argentinas de Baccharis (Asteraceae, Astereae). Darwiniana, 39(1-2): 131-154. doi:10.14522/darwiniana.2014.391-2.200.
Giuliano, D.A., and Freire, S.E. 2011. Nuevas secciones en Baccharis (Asteraceae, Astereae) de América del Sur. Ann. Mo. Bot. Gard. 98(3): 331-347. doi:10.3417/2009096.

Hayden, A. 1919. The ecologic foliar anatomy of some plants of a Prairie Province in Central Iowa. Am. J. Bot. 6(2): 69-85. doi:10.1002/j.1537-2197.1919.tb05528.x.

Heiden, G. 2009. Estudos taxonômicos e conservação em Baccharis L. (Asteraceae: Astereae) no estado do Rio de Janeiro, Brasil. M.Sc. thesis, Escola Nacional de Botânica Tropical, Rio de Janeiro, Brazil.

Heiden, G. 2019. Baccharis. In Flora do Brasil 2020 under construction. Jardim Botânico do Rio de Janeiro. Available from http://floradobrasil.jbrj.gov.br/reflora/floradobrasil/FB5151 [accessed 10 February 2019].

Heiden, G., and Pirani, J.R. 2016a. Novelties towards a phylogenetic infrageneric classification of Baccharis (Asteraceae, Astereae). Phytotaxa, 289(3): 285-290. doi:10.11646/phytotaxa. 289.3.9.

Heiden, G., and Pirani, J.R. 2016b. Taxonomy of Baccharis subgen. Tarchonanthoides (Asteraceae: Astereae: Baccharidinae), a group from the southeastern South American grasslands and savannas. Phytotaxa, 241(1): 01-70. doi:10.11646/phytotaxa. 241.1.1.

Heiden, G., Baumgratz, J.F.A., and Esteves, R.L. 2012. Baccharis subgen. Molina (Asteraceae) no estado do Rio de Janeiro, Brasil. Rodriguésia, 63(3): 649-687. doi:10.1590/S217578602012000300013.

Hellwig, F.H. 1992. Untersuchungen zur Behaarung ausgewählter Astereae (Compositae). Flora, 186: 425-444. doi:10. 1016/S0367-2530(17)30555-8.

ICMBio. 2008. Plano de Manejo do Parque Nacional da Serra dos Órgãos. Instituto Chico Mendes de Conservação da Biodiversidade (ICMBio), Brasília, DF, Brazil.

Jakovljević, K., Kuzmanović, N., Vukojičić, S., and Lakušić, D. 2014. Leaf anatomical variation in Cephalaria laevigata (Dipsacaceae) under different ecological conditions. Arch. Biol. Sci. 66(1): 161-171. doi:10.2298/ABS1401161J.

Jasinski, V.C.G., Silva, R.Z., Pontarolo, R., Budel, J.M., and Campos, F.R. 2014. Morpho-anatomical characteristics of Baccharis glaziovii in support of its pharmacobotany. Rev. Bras. Farmacogn. 24(6): 609-616. doi:10.1016/j.bjp.2014.11. 003.

Johansen, D.A. 1940. Plant microtechnique. Paul B. Hoeber Inc., New York, N.Y.

Körner, C., Neumayer, M., Menendez-Riedl, S.P., and Smeets-Scheel, A. 1989. Functional morphology of mountain plants. Flora, 182: 353-383. doi:10.1016/S0367-2530(17)30426-7.

Lersten, N.L., Czlapinski, A.R., Curtis, J.D., Freckmann, R., and Horner, H.T. 2006. Oil bodies in leaf mesophyll cells of angiosperms: overview and a selected survey. Am. J. Bot. 93(12): 1731-1739. doi:10.3732/ajb.93.12.1731. PMID:21642118.

Medri, M.E., and Lleras, E. 1980. Aspectos da anatomia ecológica de folhas de Hevea brasiliensis Müll. Acta Amazonica, 10(3): 463-493. doi:10.1590/1809-43921980103463.

Metcalfe, C.R., and Chalk, L. 1950. Anatomy of the Dicotyledons: leaves, stem and wood in relation to taxonomy with notes on economic uses. Clarendon Press, Oxford, UK.

Metcalfe, C.R., and Chalk, L. 1979. Anatomy of the Dicotyledons. Vol. I: Systematic anatomy of the leaf and stem, with a brief history of the subject. Clarendon Press, Oxford, UK.

Molares, S., González, S.B., Ladio, A., and Castro, M.A. 2009. Etnobotánica, anatomía y caracterización físico-química del aceite esencial de Baccharis obovata Hook. et Arn. (Asteraceae: Astereae). Acta Bot. Bras. 23(2): 578-589. doi:10.1590/S010233062009000200030.

Morretes, B.L. 1980. Contribuição ao conhecimento da anatomia ecológica de plantas do Cerrado de Emas - SP e da Caatinga Amazônica do Km 62 da rodovia BR 174. Qualification thesis, Universidade de São Paulo, São Paulo, Brazil. 
Mott, K.A., and Michaelson, O. 1991. Amphistomy as an adaptation to high light intensity in Ambrosia cordifolia (Compositae). Am. J. Bot. 78(1): 76-79. doi:10.1002/j.1537-2197.1991. tb12573.x

Mott, K.A., Gibson, A.C., and O'Leary, J.W. 1982. The adaptive significance of amphistomatic leaves. Plant, Cell Environ. 5(6): 455-460. doi:10.1111/1365-3040.ep11611750.

Müller, J. 2006. Systematics of Baccharis (Compositae - Astereae) in Bolivia, including an overview of the genus. Syst. Bot. Monogr. 76: 1-341.

Müller, J. 2013. World checklist of Baccharis L. (Compositae-Astereae). [Online.] Available from http://www.spezbot.uni-jena.de/wpcontent/uploads/2013/09/World-checklist-of-Baccharis-L.pdf [accessed 05 December 2018].

Nesom, G.L. 1990. Infrageneric taxonomy of North and Central American Baccharis (Asteraceae: Astereae). Phytologia, 69(1): 40-46. doi:10.5962/bhl.part.19647.

O’Brien, T.P., Feder, N., and McCully, M.E. 1964. Polychromatic staining of plant cell walls by Toluidine Blue O. Protoplasma, 59: 368-373. doi:10.1007/BF01248568.

Oliveira, A.M.A., Santos, V.L.P., Franco, C.R.C., Farago, P.V., Duarte, M.R., and Budel, J.M. 2011. Comparative morphoanatomical study of Baccharis curitybensis Heering ex Malme and Baccharis spicata (Lam.) Baill. Lat. Am. J. Pharm. 30(8): 1560-1566.

Perrone, R., Salmeri, C., Brullo, S., Colombo, P., and Castro, O. 2015. What do leaf anatomy and micro-morphology tell us about the psammophilous Pancratium maritimum L. (Amaryllidaceae) in response to sand dune conditions? Flora, 213: 20-31. doi:10.1016/j.flora.2015.03.001.

Pesacreta, T.C., and Hasenstein, K.H. 1999. The internal cuticle of Cirsium horridulum (Asteraceae) leaves. Am. J. Bot. 86(7): 923-928. doi:10.2307/2656608. PMID:10406714.

Pihakaski, K., Pihakaski, S., Karunen, P., and Kallio, P. 1987. Seasonal changes in leaf lipids of Diapensia lapponica, with special reference to storage lipid bodies. Nord. J. Bot. 7(3): 281-292. doi:10.1111/j.1756-1051.1987.tb00945.x.

Robberecht, R., Caldwell, M.M., and Billings, W.D. 1980. Leaf ultraviolet optical properties along a latitudinal gradient in the arctic-alpine life zone. Ecology, 61(3): 612-619. doi:10.2307| 1937427.
Rodriguez, M.V., Martínez, M.L., Cortadi, A.A., Bandoni, A., Giuliano, D.A., Gattuso, S.J., and Gattuso, M.A. 2010. Characterization of three sect. Caulopterae species (BaccharisAsteraceae) inferred from morphoanatomy, polypeptide profiles and spectrophotometry data. Plant Syst. Evol. 286(3): 175-190. doi:10.1007/s00606-010-0297-y.

Safford, H.D. 1999. Brazilian Páramos I: An introduction to the physical environment and vegetation of the campos de altitude. J. Biogeogr. 26(4): 693-712. doi:10.1046/j.1365-2699.1999. 00313.x.

Sanso, A.M., Aagesen, L., and Xifreda, C. 2014. Foliar anatomy and micromorphology of southern South American Alstroemeriaceae: Alstroemerieae, and its systematic implications in Alstroemeria. Nord. J. Bot. 32(6): 731-743. doi:10.1111/njb. 00470.

Sass, J.E. 1951. Botanical microtechnique. Iowa State College Press, Ames, Iowa.

Shimada, T.L., Takano, Y., Shimada, T., Fujiwara, M., Fukao, Y., Mori, M., et al. 2014. Leaf oil body functions as a subcellular factory for the production of a phytoalexin in Arabidopsis. Plant Physiol. 164(1): 105-118. doi:10.1104/pp.113.230185. PMID: 24214535.

Smiljanic, K.B.A. 2005. Anatomia foliar de espécies de Asteraceae de um afloramento rochoso no Parque Estadual da Serra do Brigadeiro (MG). M.Sc. thesis, Universidade Federal de Viçosa, Viçosa, Minas Gerais, Brazil.

Somavilla, N.S., and Graciano-Ribeiro, D. 2011. Análise comparativa da anatomia foliar de Melastomataceae em ambiente de vereda e cerrado sensu stricto. Acta Bot. Bras. 25(4): 764-775. doi:10.1590/S0102-33062011000400004.

Souza, C.A., Farago, P.V., Duarte, M.R., and Budel, J.M. 2011. Pharmacobotanical study of Baccharis singularis (Vell.) G.M. Barroso, Asteraceae. Lat. Am. J. Pharm. 30(2): 311-317.

Starr, A.M. 1912. Comparative anatomy of dune plants. Bot. Gaz. 54(4): 265-305. doi:10.1086/330917.

StatSoft Inc. 2004. Statistica: data analysis software system, version 7. Tulsa. Available from http://www.statsoft.com/.

Wilkinson, H.P. 1979. The plant surface (mainly leaf) In Anatomy of the Dicotyledons. Edited by C.R. Metcalfe and L. Chalk. Clarendon Press, Oxford, UK. pp. 97-162. 